\title{
The Effect of China's Public R \& D Policy on R \& D Expenditure of Enterprises
}

\author{
Xiting Chen \\ College of Economics, Jinan University, Guangzhou, China \\ Email: chenxt1022@163.com
}

How to cite this paper: Chen, X.T. (2018) The Effect of China's Public R \& D Policy on R \& D Expenditure of Enterprises. American Journal of Industrial and Business Management, 8, 1123-1138. https://doi.org/10.4236/ajibm.2018.85078

Received: April 11, 2018

Accepted: May 7, 2018

Published: May 10, 2018

Copyright (C) 2018 by author and Scientific Research Publishing Inc. This work is licensed under the Creative Commons Attribution International License (CC BY 4.0).

http://creativecommons.org/licenses/by/4.0/

(c) (i) Open Access

\begin{abstract}
Whether public $\mathrm{R} \& \mathrm{D}$ expenditures are complementary or crowding out of $\mathrm{R}$ \& $\mathrm{D}$ expenditures in the enterprise, there is no consensus in the academic community. This paper constructs a dynamic panel data model, uses the system GMM to estimate, and examines the impact of Chinese government R \& $\mathrm{D}$ funding on corporate $\mathrm{R} \& \mathrm{D}$ expenditures at the macro level, concluded as follow: When endogenous issues are not considered, the estimated result is that government R \& D funding will increase R \& D expenditures for enterprises, and considering endogenous issues, government $\mathrm{R} \& \mathrm{D}$ funding will squeeze out $\mathrm{R} \& \mathrm{D}$ expenditures. The government's $\mathrm{R} \& \mathrm{D}$ funding for scientific research institutions has had a significant negative impact, and the government's R \& D funding for institutions of higher learning will boost the R \& $\mathrm{D}$ investment of companies. According to the current distribution of government $\mathrm{R} \& \mathrm{D}$ funding, the impact of government $\mathrm{R} \& \mathrm{D}$ funding on corporate $\mathrm{R} \& \mathrm{D}$ expenditure is 0.3276 ; the impact of government $\mathrm{R} \& \mathrm{D}$ funding on self-raised $\mathrm{R} \& \mathrm{D}$ funds is -0.038 . It can be seen that according to the current distribution of government $\mathrm{R} \& \mathrm{D}$ funding, the effect of government $\mathrm{R} \& \mathrm{D}$ funding is crowding out.
\end{abstract}

\section{Keywords}

Public R \& D Policy, Government R \& D Funding, Corporate R \& D Expenditure

\section{Introduction}

With the rapid economic and social development of China, the extensive economic development model has become unsustainable. Changing the mode of economic development and increasing the contribution of science and technology to economic development have become China's current important tasks. 
This needs to strengthen the company's technological innovation main body position without delay and promote enterprise $\mathrm{R} \& \mathrm{D}$ activities. $\mathrm{R} \& \mathrm{D}$ activities of enterprises play an important role in improving the productivity of technological innovation and economic growth.

According to the provisions of UNESCO, scientific and technological activities include R \& D activities (research and development activities), science and technology services, and education and training. $\mathrm{R} \& \mathrm{D}$ activities refer to systematic and creative activities in the field of science and technology to increase the total amount of knowledge and use this knowledge to create new applications, including basic research, applied research, and experimental development. Therefore, R \& D activities are the core activities of science and technology activities and are the direct source of technological progress.

In recent years, China's $\mathrm{R} \& \mathrm{D}$ expenditure has been continuously increasing. According to data released by the China Statistics Bureau, in 2017, China's R \& $\mathrm{D}$ expenditure totaled 1.75 trillion yuan, an increase of $11.6 \%$ over the previous year, and the growth rate increased by 1 percentage point from the previous year. The intensity of investment in $\mathrm{R} \& \mathrm{D}$ expenditure (ratio of R \& D expenditure to GDP) was $2.12 \%$, an increase of $0.01 \%$ from the previous year. Although this is still a distance of $2.40 \%$ from the average level of OECD countries, it has exceeded the EU's average of $15.8 \%$ in 15 countries. In recent years, the intensity of $\mathrm{R} \& \mathrm{D}$ expenditures in China has been steadily increasing, and the gap with developed countries has narrowed year by year. In 2017, corporate R \& D expenditure was 1733.33 billion yuan, an increase of $13.1 \%$ over the previous year. It achieved double-digit growth for two consecutive years, and the main role of corporate innovation was further enhanced. The R \& D expenditures of government-affiliated research institutes and colleges and universities were 241.84 billion yuan and 112.77 billion yuan respectively, an increase of $7 \%$ and $5.2 \%$ respectively over the previous year.

Due to the public goods attributes externalities and high-risk characteristics of $\mathrm{R} \& \mathrm{D}$ activities, many governments have adopted various means to intervene in scientific and technological activities. The most important means is to use government funds to make up for the externalities of $\mathrm{R} \& \mathrm{D}$ activities of enterprises, reduce $\mathrm{R} \& \mathrm{D}$ risks, and promote the increase of social $\mathrm{R} \& \mathrm{D}$ investment. The target of government R \& D subsidies generally includes enterprises, colleges and universities, and government research and development institutions. Figure 1 shows the distribution of government funds in R \& D executive departments in 2015. It can be seen from the figure that the proportion of government funds obtained by the government R \& D executive departments of the United States, Japan, South Korea, Germany, and Israel is less than $50 \%$, while that of Israel is even as low as $15 \%$. The remaining government $\mathrm{R} \& \mathrm{D}$ funds are distributed among universities and corporations, as well as private non-profit organizations. Among the above countries, universities have obtained more funding allocations, at least $30 \%$ of government R \& D funds, and Israel allocates about $66 \%$ of government R \& D funds to universities; the funds obtained by 


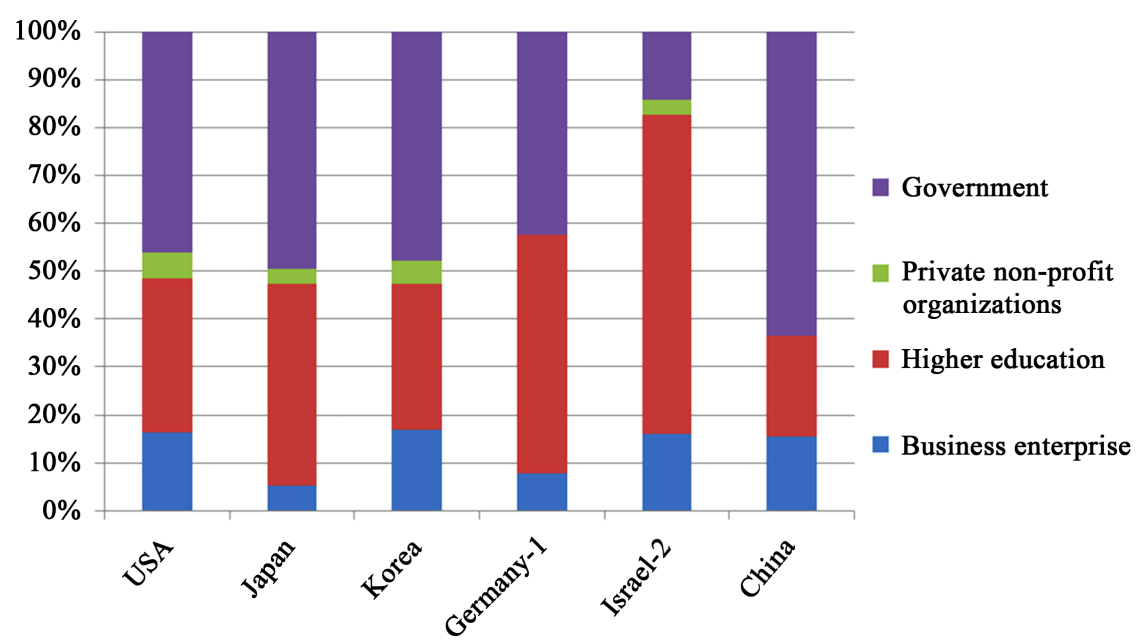

Figure 1. Distribution of government funds in R \& D executive departments. Notes: $-1=$ $2014 ;-2=2013$. Source: UNESCO institute for statistics.

companies account for about $16 \%$. In China, the distribution structure of government R \& D funds is different. Most of the government's R \& D funds are allocated to the government's $\mathrm{R} \& \mathrm{D}$ executive department, which is about $63 \%$, $21 \%$ allocated to universities, and the last $16 \%$ of government $\mathrm{R} \& \mathrm{D}$ funds obtained by companies. China's government $\mathrm{R} \& \mathrm{D}$ capital allocation structure is quite different from that of the United States, Japan, and South Korea. Judging from the proportion of government R \& D funds obtained by enterprises, China's ratio is similar to that of the United States, South Korea, and Israel, and is greater than Japan and Germany. For universities and government R \& D institutions, the above five countries have no obvious bias on the whole, but China obviously put most of the government R \& D funds into government R \& D institutions.

One of the goals of the "Thirteenth Five-Year Plan" technological innovation is to enhance the capability of independent innovation. It is necessary to make the investment intensity of research and experimental development reach $2.5 \%$, and the ratio of the $\mathrm{R} \& \mathrm{D}$ expenditures of industrial enterprises above designated size to those of main operations is $1.1 \%$. However, according to the "China Industrial Economic Report" for the first quarter of 2017 released by the Cheung Kong Graduate School of Business in June 2017, it was found that the vast majority of industrial enterprises (80\%) did not have any input in research and development; $15 \%$ of companies spend less than $5 \%$ of their R \& D expenditure on sales, while only $5 \%$ of companies spend R \& D on more than $5 \%$ of sales. From the trend point of view, the R \& D investment of industrial enterprises has decreased over the past two years.

In recent years, government $\mathrm{R} \& \mathrm{D}$ funding has continued to increase. Why does $\mathrm{R} \& \mathrm{D}$ have not reached the expected level or target level? At present, government R \& D funding mainly invests in research institutes, with a ratio of about $63 \%$. Universities and colleges account for about $21 \%$, while companies only get $16 \%$. Is this input structure reasonable? Does the choice of government 
R \& D funding have a significant impact on the effectiveness of funding? Which subjects or areas should government funding for R \& D funding be directed to? These issues are particularly important in the current context of promoting cooperation between industry, universities, and research institutes, and are unavoidable for government departments in formulating routine $\mathrm{R} \& \mathrm{D}$ policies.

\section{Literature Review}

The early normative research hypothesized that the government's R \& D activities are often inefficient, and that, in addition to military and other special purposes, the market has little demand for government $\mathrm{R} \& \mathrm{D}$ activities. If the government engages in public R \& D activities, it will not only reduce R \& D opportunities in the private sector, leading to the "crowding out" effect of private $\mathrm{R}$ \& D investment, but also making funds that would otherwise have increased total social welfare inefficiently utilized. In studies of the impact of public funds on firms' R \& D, studies such as Shrieves (1978), Carmichael (1981), and Higgins and Link (1981) support crowding out effects [1] [2] [3]. However, recent research conclusions more consistently negate the crowding out effect and tend to draw conclusions about the extra effects.

David et al. (2000) criticized earlier studies and thought they ignored the issue of sample selection bias [4]. Public R \& D subsidies tend to be distributed to certain types of enterprises in a concentrated manner, and those companies have started to conduct some R \& D work even if R \& D subsidies are not yet available, so it is easy to conclude the crowding-out effect.

Until the 1990s, most empirical studies used data from the United States, and some used Canadian or British data. Since the 1990s, most studies have used data from the European Union and other countries such as Australia, Belgium, China, Denmark, Finland, Germany, Ireland, Israel, Japan, the Netherlands, Norway, Spain, and Sweden. Research on different countries will also lead to conflicting conclusions. Empirical studies of Diamond (1999) for the United States, Duguet (2004) for France, González and Pazó (2008) for Spain, Bérubé and Mohnen (2009) for Canada, Aschhoff (2009) for Germany, Carboni (2011) for Italy, Czarnitzki et al. (2011) for Belgium, Henningsen et al. (2012) for Norway support the squeeze-in effect hypothesis [5]-[12]. On the contrary, Mamuneas and Nadiri (1996) for the United States, Busom (2000) for Spain, Wallsten (2000) for the United States and other research results support the squeeze effect hypothesis [13] [14] [15].

\section{Theoretical Basis and Effects}

Many countries adopt innovative policies to promote corporate R \& D expenditures based on the following theoretical basis. First of all, the innovative theory proposed by Schumpeter in 1934 believes that economic development is not simply a superposition of elements such as capital and labor, but that it requires a period of time to innovate and implement new production functions to achieve 
a qualitative leap in economic development. The theory of endogenous economic growth that emerged afterwards was to incorporate innovation into the production function. Corporate innovation can promote self-development, but the resulting social benefits outweigh the private benefits, and there are external uncertainties and risks. Enterprises cannot enjoy the full benefits of innovation. Therefore, the innovative products provided by the private sector are always less than the real needs of society. Public policies can encourage companies to implement independent innovations by directly allocating funds to enterprises, also public policies can generate knowledge spillovers by allocating funds to universities and government R \& D institutions, which can also promote companies to implement independent innovation. Therefore, public sector support for innovative $\mathrm{R} \& \mathrm{D}$ expenditures is essential.

However, the effect of public sector support for R \& D spending by firms may have complementary effects, may have equivocal effects, and may also have crowding-out effects. Therefore, the government's role in corporate innovation is worth studying. The innovation of this paper is to study the impact of China's overall public expenditure policy on $\mathrm{R} \& \mathrm{D}$ expenditures of enterprises from a macro perspective, which is different from previous studies at the micro and meso level. Whether the public expenditure policy is a complementary effect or a crowding-out effect, this paper has drawn different conclusions at the macro level.

\subsection{Effects of Direct Government R \& D Funding on Corporate R \& D Expenditure}

As for whether or not government R \& D funding will promote R \& D expenditures by enterprises, scholars have different opinions. Some scholars believe that government $\mathrm{R} \& \mathrm{D}$ funding can effectively reduce corporate $\mathrm{R} \& \mathrm{D}$ costs, reduce $\mathrm{R} \& \mathrm{D}$ risks, increase $\mathrm{R} \& \mathrm{D}$ expected revenues, and encourage companies to increase R \& D expenditures; some scholars believe that government R \& D funding is inefficient and will not increase R \& D expenditures of enterprises. Instead, it will squeeze out R \& D funds from companies. The theories that support government R \& D funding to increase corporate R \& D expenditures are:

1) Theory of Externalities

Since R \& D products have the characteristics of public products, R \& D activities have obvious external effects. The external effects of $\mathrm{R} \& \mathrm{D}$ activities make the R \& D income obtained by the enterprise not match the R \& D costs invested and the $\mathrm{R} \& \mathrm{D}$ risks it suffers, which reduces the $\mathrm{R} \& \mathrm{D}$ intention of the company and results in insufficient $\mathrm{R} \& \mathrm{D}$ investment. For the problems arising from the external effects of R \& D activities, government R \& D funding can stimulate $\mathrm{R} \& \mathrm{D}$ activities by reducing $\mathrm{R} \& \mathrm{D}$ costs and $\mathrm{R} \& \mathrm{D}$ risks, and give full play to the positive external effects of $\mathrm{R} \& \mathrm{D}$ activities [4] [16].

2) Signaling Theory

Due to the confidentiality, high degree of professionalism, and complexity of 
$\mathrm{R} \& \mathrm{D}$ activities, companies are often reluctant to disclose too much research and development details to potential investors, making it impossible for potential investors to accurately determine the benefits of $\mathrm{R} \& \mathrm{D}$ projects. Under such asymmetric information, it is difficult for enterprises to obtain external funds. However, if the R \& D project of the company is subsidized by the government, then the government R \& D subsidies can signal the government's support for the R \& D project, increase the investment institution's expectation of the R \& D project success rate, and reduce the investment risk perception. In this way, it can attract investment from social funds, reduce the financing constraints of enterprises, and promote the investment of companies in R \& D activities [17].

In addition to scholars who believe that government $\mathrm{R} \& \mathrm{D}$ subsidies will have a positive impact on corporate $\mathrm{R} \& \mathrm{D}$ spending, some scholars hold the opposite view that government $\mathrm{R} \& \mathrm{D}$ subsidies will not crowd into corporate $\mathrm{R} \& \mathrm{D}$ expenditures. On the contrary, they will have a negative impact on R \& D expenditures. This view has the following theoretical basis:

1) Extrusion effect theory

Assuming that the total amount of investment in R \& D activities in the society is certain, the government's subsidies for R \& D activities will squeeze out corporate funds, which will lead to a reduction in corporate funds, which will make the government subsidies lose their expected effects. On the one hand, Montmartin and Herrera (2015) believe that in the absence of a precise positioning between government investment and corporate investment, if the government subsidizes $\mathrm{R} \& \mathrm{D}$ projects that the company has financial strength to implement, then government $\mathrm{R} \& \mathrm{D}$ subsidies will directly replace R \& D expenditure [18]. On the other hand, Lach (2000) believes that companies generally only apply for $\mathrm{R} \& \mathrm{D}$ projects within the government subsidy program and reduce the willingness to subsidize unscheduled projects [16]. Therefore, government R \& D subsidies actually squeeze out corporate R \& D expenditures.

2) Element supply and demand theory

$\mathrm{R} \& \mathrm{D}$ elements are the basis for R \& D activities. The scholars represented by David (2000) and Lach (2002) believe that in the short term R \& D input factors are inelastic, and government R \& D funding will increase the demand for R \& D elements [4] [16]. Increased demand for R \& D factors will lead to an increase in prices. Such as the increase in salary levels of researchers and the rise in $\mathrm{R} \& \mathrm{D}$ equipment prices.

\subsection{Effects of $R$ \& D Funding for Universities and R \& D Institutions on Corporate R \& D Spending}

Government's direct R \& D subsidy to enterprises will have an impact on corporate $\mathrm{R} \& \mathrm{D}$ expenditures. The government's funding for higher education institutions and $\mathrm{R} \& \mathrm{D}$ institutions will also have an indirect impact on corporate $\mathrm{R}$ $\& D$ expenditures through the spillover of basic scientific and technological achievements and the transfer of scientific and technological talents. 
The types of R \& D activities in higher education institutions are mainly basic research and applied research. Compared with scientific research institutes, the cooperative relationship between higher education institutions and enterprises is closer. Enterprises and institutions of higher learning are in the upstream and downstream relations in the process of knowledge production and application, and they are also complementary relationships. Fundamental research and applied research conducted by institutions of higher learning have provided new knowledge reserves for corporate R \& D activities. The spillover of knowledge generated to companies will gradually improve the corporate $\mathrm{R} \& \mathrm{D}$ environment and reduce R \& D risks. Enterprises can use basic knowledge to conduct further technical research and development, thus increasing R \& D investment. In addition to the role of "knowledge spillovers," universities and colleges have a role to foster and deliver high-quality R \& D professionals for companies. With the increase in research and development spending of universities and colleges, it will enable them to train more $\mathrm{R} \& \mathrm{D}$ professionals. When these $\mathrm{R} \& \mathrm{D}$ professionals flow from schools to enterprises, they will increase their R \& D efficiency, reduce the risk of $\mathrm{R} \& \mathrm{D}$ activities, and increase the $\mathrm{R} \& \mathrm{D}$ expenditure of enterprises. The study by Van Pottelsberghe de la Potterie (2008) shows that the government's R \& D grants for colleges and universities has prompted companies to increase R \& D spending [19].

In general, institutions of higher learning and scientific research institutions should mainly focus on basic research and applied research to carry out R \& D activities. However, from the current point of view, scientific research institutions are mainly based on experimental development. This has a strong overlap with the R \& D investment field of enterprises and, to a certain extent, has formed a competitive relationship with companies. The government's increase in R \& D subsidies to research institutions will, to a certain extent, increase the demand for $\mathrm{R} \& \mathrm{D}$ input factors, stimulate the increase in the prices of $\mathrm{R} \& \mathrm{D}$ factors, and then increase the R \& D costs of companies, resulting in a lower R \& $\mathrm{D}$ willingness and a reduction in $\mathrm{R} \& \mathrm{D}$ investment. At the same time, $\mathrm{R} \& \mathrm{D}$ expenditures by scientific research institutions will increase scientific research results. Companies will prefer to purchase scientific research results instead of increasing their own R \& D expenditures to carry out high-risk R \& D activities.

\section{Empirical Analysis}

\subsection{Econometric Model}

In previous studies, different scholars analyzed the impact of financial science and technology investment on R \& D expenditures of enterprises at different levels of research, and the conclusions drawn from the studies will also vary. This article believes that because the financial science and technology investment policy is generally applied nationwide, and the data selected from the macro level can better illustrate the overall role of the financial science and technology investment policy on corporate $\mathrm{R} \& \mathrm{D}$ expenditures. Therefore, regional panel data 
of large and medium-sized industrial enterprises in China are used. Use the following model to estimate:

$$
\begin{aligned}
R D_{i, t}= & \beta_{0}+\alpha R D_{i, t-1}+\beta_{1} G O V_{i, t}+\beta_{2} \operatorname{INST}_{i, t}+\beta_{3} H E D_{i, t}+\beta_{4} I_{P R} R_{i, t} \\
& +\beta_{5} K_{i, t}+\beta_{6} F D I_{i, t}+\beta_{7} \operatorname{REVENUE}_{i, t}+\beta_{8} \text { OTHER }_{i, t}+\alpha_{i}+\varepsilon_{i, t}
\end{aligned}
$$

Among them, $R D$ represents $\mathrm{R} \& \mathrm{D}$ expenditures of enterprises, and $G O V$ represents government's direct $\mathrm{R} \& \mathrm{D}$ funding for enterprises. The government's $\mathrm{R} \& \mathrm{D}$ funding for scientific research institutions and the government's $\mathrm{R} \& \mathrm{D}$ funding for higher education institutions are expressed in terms of INST and $H E D$, respectively. The government has established intellectual property rights through the granting of patents and copyrights, thereby encouraging innovation activities. Therefore, the $I P R$ variable is added. Other added control variables include $K, F D I, R E V E N U E$, and $O T H E R$, which represent $\mathrm{R} \& \mathrm{D}$ capital stock, foreign direct investment, corporate main business income, and corporate $\mathrm{R} \& \mathrm{D}$ other funds.

\subsection{Endogenous Problems and Measurement Methods}

Although the use of panel data can solve the problem of missing variables to a certain extent, the vast majority of government $\mathrm{R} \& \mathrm{D}$ expenditures are not randomly allocated. Government R \& D expenditures will not only affect corporate $\mathrm{R} \& \mathrm{D}$ expenditures, but also R \& D expenditures of enterprises will affect government R \& D subsidies. Compared to non-innovative firms or non-high-tech firms, the government is likely to provide financial support to innovative and high-tech firms with higher $\mathrm{R} \& \mathrm{D}$ expenditures. Therefore, obtaining government subsidies for science and technology has become an endogenous variable for R \& D expenditures. In many studies in the past, evading research on endogenous issues led to an overall overestimation of the impact of government financial science and technology investment on corporate R \& D expenditures. Therefore, this paper adopts the method of tool variables to solve the endogeneity problems in the model.

At the same time, due to inertia, corporate $\mathrm{R} \& \mathrm{D}$ expenditures are likely to be dependent on past $\mathrm{R} \& \mathrm{D}$ expenditures. Therefore, the model includes a variable of the company's $\mathrm{R} \& \mathrm{D}$ expenditure lags as an explanatory variable, thus constructing a dynamic panel data model and estimating it using the system GMM.

\subsection{Data Description and Data Processing}

This paper uses panel data of 30 provinces in China from 2009 to 2015 (except for missing data from Tibet and Hong Kong, Macau, and Taiwan). The data comes from "China Statistical Yearbook", "China Statistical Yearbook of Science and Technology", "Statistical Yearbook of Science and Technology Activities of Industrial Enterprises" and Statistical Yearbooks by provinces. Since the main statistical indicators of the "Statistical Yearbook of Science and Technology Activities in Industrial Enterprises" were changed from "scientific and technological activities" to " $R$ \& D activities and related activities of industrial enterprises" 
after 2008, the meanings and statistical standards of related indicators have changed, so only 2009-2015 was selected to keep the data caliber uniform.

1) The explained variable Different $R \& D$ expenditure measurement methods are also one of the potential causes of different conclusions from previous studies. In general, $\mathrm{R} \& \mathrm{D}$ expenditures of enterprises can be measured in two ways: self-raised R \& D funds and total R \& D expenditures. In order to examine the impact of government $\mathrm{R} \& \mathrm{D}$ funding on the two kinds of $\mathrm{R} \& \mathrm{D}$ expenditures, this article will use the internal $\mathrm{R} \& \mathrm{D}$ expenditures of the statistical yearbook as $\mathrm{R} \& \mathrm{D}$ total expenditure data, and use enterprise fund data in the internal R \& D expenditures of the statistical yearbook as self-raised R \& D funds.

2) Explanatory variables Direct financial appropriation refers to the government's direct appropriation of enterprises for independent innovation. This article uses the government funds in $\mathrm{R} \& \mathrm{D}$ expenditures of enterprises to represent the government's $\mathrm{R} \& \mathrm{D}$ support to enterprises, which is indicated by $G O V$. Government funds refer to various types of funds from various levels of government departments in the internal R \& D expenditures of enterprises, including the actual expenditures of financial science and technology appropriations, scientific funds, education and other departmental expenses, and extrabudgetary funds of government departments.

Public R \& D spending is the country's R \& D expenditures for universities and research institutions each year. The government's $R \& D$ funding for $R \& D$ institutions uses government fund data in R \& D expenditures of R \& D institutions. Government R \& D funding for colleges and universities uses government funds data for internal $\mathrm{R} \& \mathrm{D}$ expenditures in universities.

3) Control variables The control variables include the degree of intellectual property protection, the stock of $\mathrm{R} \& \mathrm{D}$ capital of enterprises, the degree of openness of the region, other $\mathrm{R} \& \mathrm{D}$ funds of enterprises, and income from main operations.

Degree of protection of intellectual property rights: With reference to the structure and indicators of the sub-index of intellectual property protection indexed in Wang Xiaolu Fan Gang et al. "2016 China Provinces Marketization Index Report 2016", the degree of intellectual property protection was established as the number of approvals for the three types of patent applications averaged by the number of R \& D personnel.

Corporate R \& D Capital Stocks: According to the research of Bai Jun (2011), the company's R \& D capital stock is calculated using the perpetual inventory method.

Regional Openness: Regional openness is measured by the ratio of foreign investment to GDP in each region.

Enterprise R \& D Other Funds: refers to the portion of the company's total R $\& \mathrm{D}$ expenditure which is not derived from corporate funds and government funds.

In order to eliminate the impact of price changes, relevant data have been dealt with to eliminate the impact of price. 


\subsection{Regression Results without Endoccurring Issues}

Without considering the endogenous problems of direct financial appropriations, the impact of public R \& D spending policies and direct financial allocations on $\mathrm{R} \& \mathrm{D}$ expenditures of enterprises is analyzed. Table 1 reports this result.

First of all, we need to use Arellano-Bond test and Sargan test to test the validity of tool variables and the rationality of model settings. Among them, Arellano-Bond test includes Arellano-Bond AR (1) test and Arellano-Bond AR (2) test, which are used to examine whether differential residuals have first-order serial correlation and second-order serial correlation. If there is no auto-correlation, the system GMM is valid. The Sargan test is used to determine the overidentification of instrumental variables, that is, to verify that instrumental variables are valid.

Table 1. Empirical analysis without endoccurring issues.

\begin{tabular}{|c|c|c|}
\hline & \multicolumn{2}{|c|}{$R D$} \\
\hline & Total R \& D expenditure & Corporate self-raised R \& D funds \\
\hline \multirow[t]{2}{*}{$R D_{t-1}$} & $0.218^{* *}$ & $0.261^{* * *}$ \\
\hline & $(0.107)$ & $(0.0916)$ \\
\hline \multirow[t]{2}{*}{$G O V$} & $2.026^{\star * *}$ & 0.711 \\
\hline & $(0.493)$ & $(0.629)$ \\
\hline \multirow[t]{2}{*}{ INST } & $-0.520^{\star * *}$ & $-0.519 * * *$ \\
\hline & $(0.123)$ & $(0.0895)$ \\
\hline \multirow[t]{2}{*}{$H E D$} & $1.957^{\star * *}$ & $2.206^{\star * *}$ \\
\hline & $(0.644)$ & $(0.450)$ \\
\hline \multirow[t]{2}{*}{$I P R$} & $0.830^{* *}$ & $0.708^{\star *}$ \\
\hline & $(0.410)$ & $(0.349)$ \\
\hline \multirow[t]{2}{*}{$K$} & $0.0991^{* * *}$ & $0.0899^{* * *}$ \\
\hline & $(0.0242)$ & $(0.0197)$ \\
\hline \multirow[t]{2}{*}{$F D I$} & $0.756^{* * *}$ & $0.761^{* *}$ \\
\hline & $(0.226)$ & $(0.310)$ \\
\hline \multirow[t]{2}{*}{ OTHER } & $5.710^{\star * *}$ & $4.454^{* * *}$ \\
\hline & $(0.869)$ & $(0.692)$ \\
\hline \multirow[t]{2}{*}{ REVENUE } & $0.255^{\star * *}$ & $0.262^{\star * *}$ \\
\hline & $(0.0131)$ & $(0.0140)$ \\
\hline \multirow[t]{2}{*}{ Constant } & $-391,297^{* * *}$ & $-395,553^{\star * *}$ \\
\hline & $(85,402)$ & $(83,023)$ \\
\hline $\operatorname{AR}(1)$ & 0.0651 & 0.0907 \\
\hline $\operatorname{AR}(2)$ & 0.2814 & 0.3996 \\
\hline Sargan test & 0.1190 & 0.1001 \\
\hline
\end{tabular}

Note: ${ }^{\star},{ }^{*}$, and ${ }^{* *}$ indicate significance levels of $10 \%, 5 \%$, and $1 \%$, respectively; Sargan test, AR (1), and AR (2) tests all give significance probabilities $p$. 
From the results in Table 1, the AR (2) statistics of disturbance autocorrelation tests are all greater than 0.1, accepting the null hypothesis that there is no autocorrelation in the residual sequence of the residual term, indicating that the model setting is valid. In addition, over-recognition testing is also required. The results show that the Sargan test has a p-value greater than 0.1 , so at the $1 \%$ level of significance, the null hypothesis that "all instrumental variables are valid" cannot be rejected.

From the estimated results in Table 1 , the total $\mathrm{R} \& \mathrm{D}$ spending of enterprises and self-raised funds are obviously affected by the previous period. The total $\mathrm{R} \&$ $\mathrm{D}$ spending of enterprises that lags behind has a significant positive impact on the total R \& D expenditures of the current period, and the impact of the self-raised R \& D funds lagging from the first phase on the self-raised R \& D funds of the current period is also significantly positive. It shows that companies have inertia in increasing $\mathrm{R} \& \mathrm{D}$ spending.

Regardless of the endogenous issue of direct financial appropriations, the coefficient of direct R \& D expenditure on corporate R \& D expenditures is significantly positive with a coefficient of 2.026 , indicating that direct financial allocation has a significant incentive effect on $\mathrm{R} \& \mathrm{D}$ expenditures, while the direct financial appropriation has no significant effect on the self-raised R \& D expenditures of enterprises, but its coefficient is positive, indicating that the government's R \& D funding does not significantly instigate the increase of R \& D funds raised by the company.

The results in Table 1 also show that government spending on other funded targets has also significantly affected corporate R \& D expenditures. The government's R \& D funding for scientific research institutions has had a significant negative impact. The government's investment in $\mathrm{R} \& \mathrm{D}$ funding for scientific research institutions will reduce the $\mathrm{R} \& \mathrm{D}$ expenditure by 0.538 units for every additional unit funded. In contrast, the government's R \& D funding for institutions of higher learning will boost the $\mathrm{R} \& \mathrm{D}$ investment of enterprises, which has a very significant effect.

For the control variables, the degree of protection of intellectual property, the coefficient of enterprise R \& D capital stock, and the degree of openness are all significantly positive, which has a significant positive effect on the total R \& D expenditure of enterprises and self-raised R \& D funds of enterprises. In other words, the better the degree of protection of intellectual property rights, the greater the stock of R \& D capital of enterprises and the higher the degree of openness in the region, the more they will encourage enterprises to increase $R \&$ $\mathrm{D}$ expenditures.

\subsection{Regression Results When Considering Endogenous Issues}

As mentioned above, the R \& D funding of the government has a preference, which makes the R \& D funding of the enterprise not a strict exogenous variable. Therefore, the lag phase of government R \& D subsidies is used as a tool variable. Many previous studies did not consider the endogenous nature of govern- 
ment R \& D funding. In order to illustrate the impact of endogenous issues on research results, this article discusses this issue further. Table 2 gives estimates of the endogenous nature of government R \& D funding.

From the results in Table 2, the AR (1) and AR (2) statistics of disturbance autocorrelation tests are all greater than 0.1 , indicating that there is no autocorrelation of the first-order and second-order sequences of the residual items, indicating that the model setting is effective. In addition, the Sargan test has a p-value greater than 0.1 , and it can be considered that all instrumental variables are valid.

Table 2. Empirical analysis when considering endogenous issues.

\begin{tabular}{|c|c|c|}
\hline & \multicolumn{2}{|c|}{$R D$} \\
\hline & Total R \& D expenditure & Corporate self-raised $\mathrm{R} \& \mathrm{D}$ funds \\
\hline \multirow[t]{2}{*}{$R D_{t-1}$} & $0.338^{\star * *}$ & $0.347^{* * *}$ \\
\hline & $(0.0648)$ & $(0.0663)$ \\
\hline \multirow[t]{2}{*}{$G O V$} & 0.456 & $-0.512^{\star}$ \\
\hline & $(0.290)$ & $(0.284)$ \\
\hline \multirow[t]{2}{*}{$I N S T$} & $-0.504^{\star \star \star}$ & $-0.475^{\star * *}$ \\
\hline & $(0.0649)$ & $(0.0488)$ \\
\hline \multirow[t]{2}{*}{$H E D$} & $2.258^{\star * *}$ & $2.288^{\star * *}$ \\
\hline & $(0.241)$ & $(0.216)$ \\
\hline \multirow[t]{2}{*}{$I P R$} & $0.842^{\star * *}$ & $0.837^{\star * *}$ \\
\hline & $(0.191)$ & $(0.137)$ \\
\hline \multirow[t]{2}{*}{$K$} & $0.0721^{\star \star \star}$ & $0.0715^{* * *}$ \\
\hline & $(0.0155)$ & $(0.0143)$ \\
\hline \multirow[t]{2}{*}{$F D I$} & $0.586^{\star * *}$ & $0.601^{\star \star \star}$ \\
\hline & $(0.0969)$ & $(0.158)$ \\
\hline \multirow[t]{2}{*}{ OTHER } & $6.265^{\star * *}$ & $5.206^{* * *}$ \\
\hline & $(0.596)$ & $(0.797)$ \\
\hline \multirow[t]{2}{*}{ REVENUE } & $0.256^{\star * *}$ & $0.262^{* * *}$ \\
\hline & $(0.00607)$ & $(0.00687)$ \\
\hline \multirow[t]{2}{*}{ Constant } & $-377,592^{\star * *}$ & $-401,567^{\star * *}$ \\
\hline & $(68,845)$ & $(96,987)$ \\
\hline $\operatorname{AR}(1)$ & 0.3125 & 0.1981 \\
\hline $\mathrm{AR}(2)$ & 0.8144 & 0.8892 \\
\hline Sargan test & 0.4063 & 0.3954 \\
\hline
\end{tabular}

Note: ${ }^{*}{ }^{* *}$, and ${ }^{* *}$ indicate significance levels of $10 \%, 5 \%$, and $1 \%$, respectively; Sargan test, AR (1), and AR (2) tests all give significance probabilities $p$. 
In order to solve the endogenous problems of government R \& D funding, this paper uses the government's $\mathrm{R} \& \mathrm{D}$ funding lag phase as an instrumental variable. When considering endogenous issues, the coefficient of direct financial appropriation for corporate $\mathrm{R} \& \mathrm{D}$ expenditures is still positive, but it is not significant, indicating that government R \& D funding has no significant positive impact on $\mathrm{R} \& \mathrm{D}$ expenditures. Government $\mathrm{R} \& \mathrm{D}$ funding turns negative on corporate self-raising $\mathrm{R} \& \mathrm{D}$ funds, the coefficient is -0.512 , and it is significant at the $1 \%$ level, indicating that government $\mathrm{R} \& \mathrm{D}$ funding has a crowding-out effect on $R \& D$ funds raised by companies. If the government increases one unit of R \& D funding, the company's own R \& D funds will be reduced by 0.512 units.

As can be seen in Table 2, similar to the results in Table 1, the government's $\mathrm{R} \& \mathrm{D}$ funding for research institutes is significantly negative, indicating that government $\mathrm{R} \& \mathrm{D}$ spending on research institutions has a significant negative impact on $\mathrm{R} \& \mathrm{D}$ expenditures. In contrast, the government's $\mathrm{R} \& \mathrm{D}$ funding for institutions of higher learning is significantly positive, which will increase the $\mathrm{R}$ \& D investment of the company, leading to a very significant effect.

The coefficient of intellectual property protection, corporate R \& D capital stock, and regional openness coefficient are both significantly positive, which has a significant positive impact on corporate R \& D expenditure and self-raised R \& D funds.

Comparing the estimation results of Table 1 and Table 2, we can see that the endogenousness of government R \& D funding has a significant impact on the estimation result. When the endogeneity problem is not considered, the estimated result is that government $\mathrm{R} \& \mathrm{D}$ funding will increase $\mathrm{R} \& \mathrm{D}$ expenditures. After considering endogenous issues, the opposite result is drawn: Government R \& D funding will squeeze out R \& D expenditures. This shows that if we do not deal with endogenous issues, we will overestimate the impact of government R \& D funding on corporate R \& D spending.

The results of the public $\mathrm{R} \& \mathrm{D}$ expenditure policy are consistent in the two tables. The government's R \& D funding for scientific research institutions has had a significant negative impact on corporate $R \& D$. The government's R \& D funding for higher education institutions will boost the $\mathrm{R} \& \mathrm{D}$ investment of enterprises. It can be seen that the government should increase R \& D funding for this part, maintain the systematic nature of $\mathrm{R} \& \mathrm{D}$ activities, and guide enterprises to increase $\mathrm{R} \& \mathrm{D}$ investment. As we all know, $\mathrm{R} \& \mathrm{D}$ activities in the three areas of basic research, applied research, and experimental development are mutual influence, mutual restraint, and organic unity. If we do not pay attention to basic research and do not increase funding for it, we will not be able to provide strong support for the follow-up links. Application research and trial development will be affected, and the efficiency and effectiveness of R \& D activities will be reduced.

From the average R \& D funding level of the Chinese government, R \& D funding received by scientific research institutions accounts for about $63 \%$ of the 
total, only $21 \%$ for higher education institutions, and $16 \%$ for companies. According to this ratio, the impact of the $\mathrm{R} \& \mathrm{D}$ funding from the Chinese government on the total R \& D expenditure of the company is $0.230\left(0.456{ }^{*} 16 \%+\right.$ $2.258 * 21 \%-0.504 * 63 \%)$. That is, for each additional unit of government R \& $\mathrm{D}$ funding, the total R \& D expenditure of the company can be increased by 0.230 units. The impact of the $\mathrm{R} \& \mathrm{D}$ funding from the Chinese government on the self-raised R \& D funds of the company is $0.099(2.288 * 21 \%-0.475 * 63 \%$ $-0.512 * 16 \%)$. That is, for each additional unit of government R \& D funding, enterprises can be encouraged to raise R \& D funds by 0.099 units. It can be seen that, according to the current distribution of government R \& D funding, government $\mathrm{R} \& \mathrm{D}$ funding has contributed to the $\mathrm{R} \& \mathrm{D}$ spending of companies. If government R \& D funding continues to favor scientific research institutions, the government's R \& D funding effect will be greatly reduced from the perspective of promoting enterprise R \& D investment. The government should invest more R \& D funding in higher education institutions, which is more conducive to the promotion of $\mathrm{R} \& \mathrm{D}$ investment by enterprises.

\section{Conclusions and Policy Recommendations}

Whether public R \& D expenditures are complementary or crowding out of R \& $\mathrm{D}$ expenditures in the enterprise, there is no consensus in the academic community. This paper selects panel data of Chinese large and medium-sized industrial enterprises from 2009 to 2015, constructs a dynamic panel data model, uses the system GMM to estimate, and examines the impact of government R \& D funding on $\mathrm{R} \& \mathrm{D}$ expenditures at the macro level. The conclusions are as follow:

1) When endogenous issues are not considered, the estimated result is that government R \& D funding will increase R \& D expenditures for enterprises, and considering endogenous issues, government R \& D funding will squeeze out R \& $\mathrm{D}$ expenditures. The government's R \& D funding for scientific research institutions has had a significant negative impact, and the government's R \& D funding for institutions of higher learning will boost the $\mathrm{R} \& \mathrm{D}$ investment of companies.

2) According to the current distribution of government $R \& D$ funding, the impact of government $\mathrm{R} \& \mathrm{D}$ funding on corporate $\mathrm{R} \& \mathrm{D}$ expenditure is 0.3276 ; the impact of government R \& D funding on self-raised R \& D funds is -0.038 . It can be seen that according to the current distribution of government R \& D funding, the effect of government R \& D funding is crowding out. If government $\mathrm{R} \& \mathrm{D}$ funding continues to favor scientific research institutions, the government's R \& D funding effect will be greatly reduced from the perspective of promoting enterprise $\mathrm{R} \& \mathrm{D}$ investment. The government should invest more $\mathrm{R}$ \& D funding in higher education institutions, which is more conducive to the promotion of R \& D investment by enterprises.

For these conclusions, this paper proposes the following policy recommendations:

1) China's current R \& D intensity is far from the developed countries such as 
the United States and Japan. The government should vigorously increase R \& D funding and continue to adopt various means to guide the community to increase the total amount and intensity of $\mathrm{R} \& \mathrm{D}$ funding. The crowding-out effect of government R \& D funding may be due to the inadequate supervision of financial science and technology funds and the inefficient use of funds. In order to maximize the utility of government R \& D funding, China should speed up the improvement of the supervision mechanism for science and technology investment, adopt a more effective and transparent supervision mechanism, increase supervision, and increase the efficiency of the use of financial science and technology funds, and choose a diversified financial investment method.

2) While the government is increasing $R \& D$ funding, more important work is to improve the input structure of government $R \& D$ funding. Government $R$ $\& \mathrm{D}$ funding targets should be tilted from research institutions to companies and universities. The government should invest as much as possible into enterprises and institutions of higher learning, in addition to guaranteeing some funding guarantees for scientific research institutions in connection with national defense and major technological breakthroughs, which will help stimulate the company's own R \& D funding. In the current context, the government should use R \& D funds to fund the formation of a production-university-research cooperation model with enterprises as the mainstay, and strengthen the role of the enterprise as a technological innovation subject. Instead of simply investing in $\mathrm{R}$ $\& D$ activities of research institutions that are repetitive and highly competitive with $\mathrm{R} \& \mathrm{D}$ companies, the government should directly invest the $\mathrm{R} \& \mathrm{D}$ funds of industry and research alliance to the enterprise. This will not only help guide the increase in $\mathrm{R} \& \mathrm{D}$ investment of enterprises, but also help solve $\mathrm{R} \& \mathrm{D}$ expenditures of research institutions and increase the promotion rate of scientific and technological achievements.

At the same time, the government should increase funding for basic research, and should guide universities and research institutes to pay more attention to basic research and increase the proportiSSon of funds invested in basic research. Strengthening basic research can maintain the continuity and systematicness of R \& D activities, provide necessary support for follow-up R \& D activities, and can avoid crowding-out effect of $\mathrm{R} \& \mathrm{D}$ investment. China's current basic research funding is far from enough. The investment ratio is only $5.2 \%$, while the developed countries are between $10 \%$ and $20 \%$.

\section{References}

[1] Shrieves, R.E. (1978) Market Structure and Innovation: A New Perspective. Journal of Industrial Economics, 26, 329-347. https://doi.org/10.2307/2098078

[2] Carmichael, J. (1981) The Effects of Mission-Oriented Public R \& D Spending on Private Industry. Journal of Finance, 36, 617-627. https://doi.org/10.1111/j.1540-6261.1981.tb00648.x

[3] Higgins, R.S. and Link, A.N. (1981) Federal Support of Technological Growth in Industry: Some Evidence of Crowding out. IEEE Transactions on Engineering 
Management, 28, 86-88. https://doi.org/10.1109/TEM.1981.6447450

[4] David, P.A., Hall, B.H. and Toole, A.A. (2000) Is Public R \& D a Complement or Substitute for Private R \& D? A Review of the Econometric Evidence. Research Policy, 29, 497-529. https://doi.org/10.1016/S0048-7333(99)00087-6

[5] Diamond, A.M. (1999) Does Federal Funding "Crowd in" Private Funding of Science. Contemporary Economic Policy, 17, 423-431. https://doi.org/10.1111/j.1465-7287.1999.tb00694.x

[6] Duguet, E. (2004) Are R \& D Subsidies a Substitute or a Complement to Privately Funded R \& D? Evidence from France Using Propensity Score Methods for Non-Experimental Data. Revue D'Economie Politique, 114, 263-292. https://doi.org/10.3917/redp.142.0245

[7] González, X. and Pazó, C. (2008) Do Public Subsidies Stimulate Private R \& D Spending? Research Policy, 37, 371-389. https://doi.org/10.1016/j.respol.2007.10.009

[8] Bérubé, C. and Mohnen, P. (2009) Are Firms That Receive R \& D Subsidies More Innovative? Canadian Journal of Economics, 42, 206-225. https://doi.org/10.1111/j.1540-5982.2008.01505.x

[9] Aschhoff, B. (2009) The Effect of Subsidies on R \& D Investment and Success. Do Subsidy History and Size Matter? ZEW Discussion Paper No. 032, Mannheim.

[10] Carboni, O.A. (2011) R \& D Subsidies and Private R \& D Expenditures: Evidence from Italian Manufacturing Data. International Review of Applied Economics, 25, 419-439. https://doi.org/10.1080/02692171.2010.529427

[11] Czarnitzki, D., Hottenrott, H. and Thorwarth, S. (2011) Industrial Research versus Development Investment: The Implications of Financial Constraints. Cambridge Journal of Economics, 35, 527-544. https://doi.org/10.1093/cje/beq038

[12] Henningsen, M., Haegeland, T. and Møen, J. (2012) Estimating the Additionality of R \& D Subsidies Using Proposal Evaluation Data to Control for Firms' R \& D Intentions. Statistics Norway Discussion Paper, 729.

[13] Mamuneas, T.P. and Nadiri, M.I. (1996) Public R \& D Policies and Cost Behavior of the US Manufacturing Industries. Journal of Public Economics, 63, 57-81. https://doi.org/10.1016/S0047-2727(96)01588-5

[14] Busom, I. (2000) An Empirical Evaluation of R \& D Subsidies. Economics of Innovation and New Technology, 9, 111-148. https://doi.org/10.1080/10438590000000006

[15] Wallsten, S.J. (2000) The Effects of Government-Industry R \& D Programs on Private $\mathrm{R} \& \mathrm{D}$ : The Case of the Small Business Innovation Research Program. RAND Journal of Economics, 31, 82-100.

[16] Lach, S. (2002) Do R \& D Subsidies Stimulate or Displace Private R \& D? Evidence from Israel. Journal of Industrial Economics, 50, 369-390. https://doi.org/10.1111/1467-6451.00182

[17] Kleer, R. (2010) Government R \& D Subsidies as a Signal for Private Investors. Research Policy, 39, 1361-1374. https://doi.org/10.1016/j.respol.2010.08.001

[18] Montmartin, B. and Herrera, M. (2015) Internal and External Effects of R \& D Subsidies and Fiscal Incentives: Empirical Evidence Using Spatial Dynamic Panel Models. Research Policy, 44, 1065-1079. https://doi.org/10.1016/j.respol.2014.11.013

[19] Van Pottelsberghe de la Potterie, B. (2008) Europe's R \& D: Missing the Wrong Targets. Intereconomics, 43, 220-225. https://doi.org/10.1007/s10272-008-0254-y 